\title{
9. Klein in Bali and Ilahita: A reflection on cultural fantasy and the deep unconscious
}

\author{
Michele Stephen
}

\begin{abstract}
Although many anthropologists would not even accept the existence of a deep unconscious such as outlined by psychoanalytic theory of various persuasions, the ethnographic data often provide examples of cultural constructs that seem such vivid realisations of themes described in psychoanalytic practice that one can only stand amazed. If there is no 'unconscious', from whence do these extraordinary visions emerge and how is it they have such constancy across cultures? In this chapter, I employ Melanie Klein's work on gender, fantasy and psychosocial development as a framework for comparing Balinese and Ilahita imaginings of the feminine and the maternal.
\end{abstract}

If Freud's insights concerning the region of the unconscious were unpalatable to many - dethroning as they did reason and consciousness as the sources of human motivation-Melanie Klein's theories might be considered truly repellent. At least Freud's theories put the father figure and patriarchal authority at the centre of unconscious conflict. Klein, however, was bold enough to declare that the real lynchpin of all emotional development was the relationship with the mother. Prior to the unconscious guilt attached to a fantasised patricide went envy and paranoid fears aroused by a fantasised matricide. Masculinity and femininity were shaped against a mother image of such terrible power that both genders felt themselves to be damaged as a result of the struggle. In Klein's view, human life began in pain and suffering; it was not an optimistic view of the human condition. Yet she believed that it was only in relationships that emotional life developed and she emphasised that guilt, envy and fear were balanced by an equally strong positive urge to make reparation.

Contemporary feminist theorist Julia Kristeva (2001:15) observes: 'Melanie Klein ranks amongst those who have done the most to further our understanding of our being as an endemic state of ill-being in all its diverse manifestations: schizophrenia, psychosis, depression, mania, autism, delays and inhibitions, catastrophic anxiety, fragmentation of the ego, and so forth.'

Although Klein took psychoanalysis in new directions, she did so within the framework of Freudian thought. Kristeva (2001:11) notes: 'Klein successfully introduced a new approach to the theory and practice of the unconscious without ever abandoning the fundamental principles of Freudianism 
(which distinguishes her from Jung and from the other "dissidents").' Her significance for anthropology is perhaps only beginning to emerge, especially as anthropology's comparatively recent interest in gender directs new attention to the maternal in cultural fantasy (Gregor and Tuzin 2001). I do not expect that my readers will find Klein's ideas more intuitively persuasive than Freud's; quite the contrary. Yet I contend that she has much to offer anyone who seeks to explore the extraordinary images of the maternal found in Bali and Melanesia.

The inspiration for this chapter goes back several years to when I first began to take an interest in Kleinian theory. Don Tuzin commented to me at the time that his mentor at The Australian National University, Derek Freeman, always said that the Hindu goddess Durga was a Kleinian fantasy par excellence. Later, when I came to work in Bali, Indonesia, I began to understand why, and I promised myself that one day I would attempt a Kleinian interpretation of Durga. It thus seems especially fitting that I should offer this essay as a tribute to Don's wideranging psychoanalytic and comparative interests. In the process of writing, I began to realise that Klein's ideas not only threw new light on my Balinese material but also strongly resonated with Don's own work on masculinity and femininity among the Ilahita. I had previously published a piece on male cults in the New Guinea Highlands from a Kleinian perspective (Stephen 2003); I began to wonder how the same approach might work with respect to Sepik male cults. Engaging with Don's analysis of the Ilahita cult enables me to identify significant points of similarity and difference with Balinese imagery of the 'Terrible Mother', pointing to the ways in which cultures deploy to different ends, and with different consequences, imagery drawn from the deep unconscious. My Kleinian framework also brings me to challenge some aspects of Don's analysis of the male cult, as will be explained later. In doing so, I seek to honour the fertile and stimulating qualities and the breadth of Don's theoretical reach.

This chapter is not offered as ethnography but as an interpretation that draws upon extensive bodies of ethnographic work, sketching in with bold brush strokes links and parallels leading to reflections upon the nature of masculinity and femininity as shaped by culture and the unconscious. My arguments and conclusions do not pretend to be conclusive but aim to draw new attention to the mystery of the maternal, especially its negative aspects, in cultural imaginings. I begin with the horrific imagery of the Balinese Durga ${ }^{1}$ and then turn to a consideration of the role of similarly Terrible Mothers among the Ilahita of New Guinea.

\footnotetext{
1 I have elsewhere described the Balinese goddess Durga (Stephen 1999, 2001, 2005, 2006), but have not previously attempted a psychoanalytic interpretation of her iconography, except to the extent that it is connected to the witch figure.
} 


\section{Klein and Durga in Bali}

The Divine Mother has many refractions in Hinduism, and Durga is one of the most prominent. In Indian iconography, Durga is a warrior goddess, her 10 arms each carrying a weapon, riding on a lion into battle. Yet, though she is bloodthirsty, and offerings to her consist of meat and blood, she is usually depicted as young and beautiful in form. She is addressed as 'Ma Durga'Mother Durga - and praised as defender and saviour by her followers. She seems to stand midway between gentle and benign forms of the goddess such as Sri and Sarasvati, and horrific forms such as Camundi and Kali (Kinsley 1988).

Durga is defined thus in the Rider Encyclopaedia of Eastern Philosophy and Religion:

'[T] he unfathomable one'; one of the oldest and most widely used names for the Divine Mother, the consort of Shiva.

Her ten-armed figure, standing on the back of a lion, symbolizes the great power that the Vedic texts describe her as wielding, either to punish or to confer grace on human beings. She destroys the demon of ignorance, nourishes the poor, and confers blessings of love and knowledge upon all those who strive for God-realization. (Schumacher and Woerner 1999:96)

The Balinese Durga ${ }^{2}$ differs from her Indian counterpart, although both figures might be said to be recognisable as variations on similar themes. Indian traditions seem to emphasise Durga as a warrior goddess. ${ }^{3}$ She is revered as the slayer of terrible demons - in particular, the buffalo demon, Mahisha. In this form of demon slayer, and thus as the saviour of gods and humans, she is usually depicted as a young and beautiful woman. Durga, the slayer of the demon Mahisha, is known in Bali, and her image is found in old Javanese sculpture. A famous statue of Durga at Pura Kedarman in Bali depicts the goddess in human form, ${ }^{4}$ but the Balinese Durga is more usually depicted very differently. Her iconography more closely resembles the Indian goddess Kali, a horrific manifestation of Durga.

\footnotetext{
2 The relationship between Balinese Hinduism and Hinduism (in its many varieties) as found in India has been the topic of much scholarly debate over many years, with some scholars arguing that at best Hinduism in Bali is but skin deep, and others that it is much more deeply rooted (see Stephen 2005). I do not intend to re-enter that debate here but to describe the imagery of the Terrible Mother as encountered in its specifically Balinese cultural forms. My aim is not to compare the Balinese and Indian variants of the goddess - a project well worth undertaking but one that could not be contained within the limits of a single essay. Emigh (1996:89) suggests that the iconography of the Balinese Durga/Rangda might be derived from several different Indian goddesses. Overall, his exploration of the Balinese Rangda clearly demonstrates the ways in which she encapsulates many aspects of the Shakti traditions of India.

3 Variations in the role of goddess over time and in different regions of India are, however, noted by Kinsley (1988:96, 114-15).

4 See Bernet Kempers (1991:32) for an illustration; compare with Mookerjee (1988:48).
} 
As the Divine Mother, Kali is usually represented as dancing or in sexual union with Shiva. Whereas Shiva represents the transcendental aspect, Kali symbolizes the dynamic aspect, primal energy...Kali wears a belt made of dismembered arms and a necklace of skulls; of her four arms, the lower left hand holds the bloody head of a demon, the upper left wields a sword. With her upper right hand she makes a gesture of fearlessness, while the lower right hand confers benefits. She destroys ignorance, maintains the world order, and blesses and frees those who strive for the knowledge of God. Kali is the symbol of dissolution and destruction. (Schumacher and Woerner 1999:170)

Kali is usually shown with staring eyes, a red, lolling tongue, sharp fangs and fierce expression; her skin is black and her hair long, matted and wild (see Mookerjee 1988 for illustrations). When she appears with Shiva, her spouse, she usually stands or sits astride his recumbent body.

The Balinese Durga is depicted in temple sculpture and paintings as a kind of female monster or ogress, the body large and heavy, with emphasis on pendulous breasts and belly, the head like that of a wild beast. She is gigantic in size, as is the mother in respect to the infant. With great bulging eyes, a pig-like snout, huge curved fangs and a great gaping maw opened to release a flaming red tongue, her face is that of a terrifying animal. A mass of matted, tangled hair cloaks her back and sides, reaching to the ankles. Her feet and hands have the huge claws of a beast of prey. Entrails, bones and dismembered human body parts constitute her necklaces, earrings and various ornaments. How does such a hideous figure come in Bali to represent the Divine Mother?

Balinese mythic representations reveal that Durga is the terrible form taken by the gentle and beautiful goddess Uma, ${ }^{5}$ wife of Siwa (Shiva). As Siwa's sakti, Uma is the active creative principle that gives rise to the physical world and all its contents. She is the Divine Mother as creatrix; however, myths recount that having created the world and human beings, Uma suddenly turned upon her creations in anger and, taking the terrible shape of Durga, began to destroy them. The Purvaka Bhumi, a Balinese text explaining the origin of the universe, describes the goddess's horrific transformation thus:

The Goddess then looked upon Her Self

And full of wrath She then became.

Her urge was then to eat mankind;

She screamed, and like a lion roared.

Her teeth were long and sharp, like tusks,

Her mouth an abyss in between,

5 'Uma' is more common than 'Parvati' as the name of Shiva's divine consort in Bali, while 'Shiva' is usually pronounced and spelt 'Siwa' or 'Ciwa'. 
Her eyes shone, they were like twin suns,

Her nostrils, deep and cavernous.

Her ears stood like two thighs, straight up,

Matted and twisted was her hair;

Her body was misshapen, huge,

There was nothing that broke its height.

It pierced The Egg of the Universe,

Reached to the centre of the Sky.

Such then, was the Goddess Durga,

That was the name that She then bore. (Hooykaas 1974:64-5)

The myth continues with the god Siwa (Shiva) also taking the form of the terrible god Kala. Together, Durga and Kala create all manner of hideous creatures, and, residing in the graveyard, they begin to feast on humankind:

Could then the Goddess have been seen,

She was arising from the Deep,

And with her was the God Kala,

What was the aspect She had then?

With blood, as ashes, She was smeared,

And garlanded with human skulls,

Intestines were draped over Her,

She wore a scarf of red and black.

Her minions were escorting Her,

The creatures of the God Kala,

With all their brood attending them.

Then in the graveyard She did dwell.

In the graveyard of the infants,

Uncanny trees, branches drooping,

Where the God Kala's creatures dwelt,

The frenzied Dremba ate mankind. (Hooykas 1974:71)

Various myths recount how Siwa provoked Uma's anger, causing her to descend to the Earth as Durga and wreak destruction upon its inhabitants (Stephen 2002, 2005:64-71). Other myths attribute to her the origin of disease and of witchcraft (Stephen 2006). Human beings who aspire to obtain destructive occult powers (pengiwa) must pray to Durga in the cemetery in order to obtain them, and all human witches are said to be her followers and servants. She resides in the Pura Dalam (one of the three temples found in every Balinese village), where the souls of the dead awaiting cremation also stay. Clearly, she is associated with death, disease, witchcraft and destruction.

Durga is the inspiration for various sacred dances/dramas in which two formidable monsters, Barong and Rangda, confront each other, apparently 
in battle, but one in which no side is ever victorious. Rangda is danced by a single performer wearing a long wig of matted hair, a fearsome mask and striped bodysuit representing a grotesque female form. Her opponent, Barong, is danced by two performers, one carrying the front and the mask, the other the rear end with its long, arched tail. The body of the Barong is covered with long black, and sometimes white, hair and gives the impression of a great hulking beast, yet he has about him an air of both the ludicrous and the playful. I have elsewhere interpreted these two figures in detail to reveal their mystic significance as the goddess Durga and her spouse, the god Siwa, in his terrible form as Siwa Kala (Stephen 2001, 2005). Their ritual encounter in dance depicts the occasion quoted earlier in which Durga and Kala meet on Earth to create all terrible and destructive entities. As the PurvakaBhumi explains, in their divine forms, the goddess Uma and the god Siwa create the world, human beings and all good and useful creatures, then in their terrible forms as Durga and Kala they create fearsome and destructive entities. The aim of human ritual, while recognising the negative aspect of creation, is to ensure that Durga and Kala never again devour mankind but instead are persuaded to assume their benign forms as Uma and Siwa and to return to Heaven. The PurvakaBhumi tells that human beings were taught how to make the offerings necessary to satisfy the terrible hunger of Durga and Kala and their minions:

And then a covenant they made:

That mankind in the Middle Sphere,

At full of moon and when at new,

Should not by Kala be accurst,

Should not by Durga be accurst.

God Kala shall not eat of him,

The Goddess Durga eat him not;

..

Gone is the form that They then had,

To their first form They have returned;

God Kala, Guru has become,

And Durga, Uma has become. (Hooykaas 1974:75)

The aim of Balinese ritual is to ensure that the capacity for divine forces to turn destructive is balanced by the return to a positive state. Through ritual action, all negative, coarse and dangerous forces and entities can be transformed back into the positive entities from which they originated (Stephen 2002, 2005).

The dangerous and disruptive entities created by Durga and Siwa Kala - the bhutakala - can be transformed from enemies into protectors and guardians. Furthermore, since Durga and Kala gave rise to these entities, they control them and thus in terrible form can provide protection from them. The masks of Rangda and Barong used in the sacred dance dramas are kept in the village temples, 
along with other sacred symbols. Collectively, these items are referred to as the 'sesuhunan'. ${ }^{6}$ The Rangda and Barong masks are brought out and displayed on various occasions, and are revered as the protectors and guardians of the village, although not all people are aware of their mystical significance as emanations of Uma and Siwa. One hears much more of Durga in Bali than of Uma, her benign, gentle form, and her ferocious images are much more evident.

\section{Kleinian Perspectives on the Terrible Mother}

Durga/Kali, as found in India or Bali, is such a repellent image that one can only imagine how colonialists from Britain and Europe must have shuddered at such strange expressions of religious fervour (Urban 2003). What could be more disgusting, more alien - an ultimate manifestation of 'otherness' - for nineteenth-century European minds? No wonder even today the very name Durga tends in the popular imagination to conjure images of blood-soaked temples and thuggery. There is little or nothing here to overtly suggest commonality across cultures, so repellent is Durga/Kali that she surely must be the creation of a specific cultural logic, or fantasy. Ostensibly, she provides a case in point for the anthropological perspective that only an elucidation of the cultural webs of significance in which such a figure is enmeshed could provide any understanding of it. Intuitively, we can see no common ground with such a figure. Why should the Great Mother, the cosmic principle of creativity, be described in such extraordinarily ambivalent terms? Why in Bali is the tender, nurturing beautiful Mother equally a hideous monster who devours her own young and wreaks disease, havoc and destruction on all? What in these cultures might give rise to such horrific images of the feminine and place such emphasis on the hideous and grotesque in the maternal figure?

Freudian approaches lead to the assumption or argument that Indian child-rearing practices give rise to the splitting of the mother figure, and more specifically to the horrific image of Kali. ${ }^{7}$ Are we to assume that the same arguments might explain the Balinese images? Some very famous anthropologists have certainly thought so, and have attempted to explain the figure of Rangda as a product of Balinese child rearing (Bateson and Mead 1942). But can child-rearing practices alone account for the sheer horror and force of such imaginings?

If we turn to the pages of psychoanalyst Melanie Klein (a younger contemporary of Freud), we can find descriptions of the fantasies of Western individuals

6 The sesuhunan are sacred objects representing divine powers, including masks and other items, belonging to the village temples.

7 Freudian interpretations of Kali have been extensively explored by Jeffrey Kripal (2003:196-222). 
concerning the mother figure that closely parallel, in all their grotesque detail, the Balinese iconography of Durga. A Kleinian perspective thus might lead us to give more weight to unconscious sources of such cultural imagery.

Klein's psychoanalytic theories of emotional development came to focus on the persecutory anxieties and fears experienced by the human infant from its earliest moments from birth onwards. She argued that the first six months of the child's life were dominated by what she came to refer to as the 'paranoid/ schizoid position', which then gradually moved into a phase she referred to as the 'depressive position' (Klein 1993a:2-4). These two crucial developmental phases were what in Klein's view determined all later and adult emotional adjustment. Furthermore, failure to move through each phase satisfactorily became the basis for neurosis and even psychosis in later life.

In the paranoid-schizoid phase, the infant is exposed to an external world of experiences totally beyond its capacity to control or understand. In its relation to its primary care giver - usually the actual mother - the infant is totally dependent on her to satisfy all its basic needs. This first 'other' is initially experienced by the infant as a series of pleasurable, satisfying and comforting sensations - as when fed or held at the breast, and touched and handled in a comforting manner-and a series of painful, frightening and frustrating sensations, when the infant is hungry, wet, cold or in pain. Thus, in Klein's view, a sense of a good, satisfying external object is built up on the one hand, and on the other, a bad, frustrating and persecutory object. At first, due to its emerging cognitive capacities, the infant does not understand that the 'good object' and the 'bad object' are parts of the one person, the mother. Klein refers to this process as 'splitting' and to the 'good breast' and the 'bad breast' as the two objects or images that form in the infant's mind. Only later, as the child reaches the depressive position, does it begin to realise that the two are aspects of the one person.

'Splitting' along with projection and introjection become important defence mechanisms against anxiety during this early phase and later. Through projection, the nascent ego is able to rid itself of badness and danger, and, through introjection, it is able to incorporate the good object within itself (Klein 1993a:6-7). By splitting, the ego is able to keep the good object, the 'good breast', totally separate from the bad, frustrating breast, thus not only are the two kept widely apart but the very existence of the bad can be denied (at least for a time). In other words, the initial ambivalence in which experience of the mother is grounded also serves to protect the infant ego from realising that good and bad sensations emanate from the same external source. The infant 'phantasises' ${ }^{8}$ the

8 In Kleinian theory, the term 'phantasy' is employed to indicate unconscious imaginative processes taking place outside conscious awareness, as distinct from 'fantasy', which takes place in consciousness. See 
destruction of the bad breast while still being able to keep intact in its mind the good object. Thus, the complex process of introjection of good, and projection of the bad, can take place. Klein points out, however, that projecting the bad has its costs as it also involves denial and annihilation of a part of the ego - that part from which the bad feeling towards the object emanates (Klein 1993a:7).

Overwhelmed by its fears of the persecutory object - the 'bad breast' - the infant comes to hate it and wishes to destroy it by whatever means possible. Accordingly, it begins to picture, in the imagery thought that is all that is available prior to the development of language, retaliatory attacks upon the 'bad breast'. These attacks take the form of biting, chewing and burrowing into the 'bad breast', tearing into it with nails and teeth and sucking out all its contents. Klein (1993b:63) explains:

If we consider the picture which exists in the infant's mind-as we can see it retrospectively in the analyses of children and adults - we find that the hated breast has acquired the oral-destructive qualities of the infant's own impulses when he is in states of frustration and hatred. In his destructive phantasies he bites and tears up the breast, devours it, annihilates it; and he feels that the breast will attack him in the same way. As urethral- and anal-sadistic impulses gain in strength, the infant in his mind attacks the breast with poisonous urine and explosive faeces, and therefore expects it to be poisonous and explosive towards him. The details of his sadistic phantasies determine the content of his fear of internal and external persecutors, primarily of the retaliating (bad) breast. (Klein 1993b:63)

Klein recognises that this picture of a terrified infant trying to defend itself against a hated persecutor who is none other than an internal representation of its mother seems scarcely credible given our assumptions about the angelic innocence of babies. Nevertheless, she argues that the evidence is undeniable for those familiar with the clinical data:

The idea of an infant of from six to twelve months trying to destroy its mother by every method at the disposal of its sadistic trends - with its teeth, nails and excreta and with the whole of its body transformed in phantasy into all kinds of dangerous weapons - presents a horrifying, not to say an unbelievable picture to our minds. And it is difficult, as I know from my own experience, to bring oneself to recognize that such an abhorrent idea answers to the truth. But the abundance, force and multiplicity of the cruel phantasies which accompany these cravings are displayed before our eyes in early analyses so clearly and forcefully that 
they leave no room for doubt. We are already familiar with those sadistic phantasies of the child which find their culmination in cannibalism, and this makes it easier for us to accept the further fact that as its methods of sadistic attack become enlarged so do its sadistic phantasies gain in fullness and vigour. (Klein 1994:130)

These escalating sadistic trends in turn give rise to more and more horrific images of the persecutor and what might be expected in retaliation. Thus, as the child begins by desiring to attack the 'bad breast' by sucking and scooping it out, then later by tearing into it with teeth and nails, and finally with explosive excreta and burning urine, so it expects to be annihilated by the 'bad breast' in exactly the same manner. Eventually, these desires move to the mother's body as a whole, which the infant desires to pierce open, burrow into and rob of all its desired contents - that is, those things the child assumes she is withholding for her own pleasure: milk, excrement, babies, and, by this stage, the father's penis. So the child comes to imagine a Terrible Mother figure that desires to rip open, suck dry and devour him. Klein (1993b:62) stresses the dominance of oral greed and aggression in this situation.

As the child develops, however, it begins to fear that, in its imagined attacks upon the bad breast/mother, it might have injured or destroyed the 'good breast' on which it depends for every comfort and need. This fear ushers in the next phase of development: the 'depressive position', where remorse and guilt over damaging or killing the 'good mother' prevail over paranoid fears of attack by the 'bad mother'. In order to deal with the feelings of loss that now emerge, the child must engage in reparative phantasies in which the damaged, wounded or dead mother is put back together and returned to life. The depressive position comes into play somewhere towards the beginning of the second half of the first year of life.

The first year of life begins with phantasies concerning sadistic attacks upon the bad mother and, in turn upon the self; then, as the child begins to realise that the good and bad breast are aspects of the one person (the mother), it is dominated by fears of loss, guilt and remorse. The splitting of the experience of the mother is determined at first by the infant's limited mental capacity, as it seeks to attach sensations - pleasurable and painful - to imagery. But as the child develops, the splitting begins to serve as a defence mechanism, shielding the child from recognising that the two are actually one.

From a Kleinian perspective, we see that the child's emotional life is dominated by the mother imago - that is, the internal image generated in the child's mind. All pleasurable and negative experiences are linked to aspects of this figure, and dealing with the love, hate, fear, remorse and guilt that it evokes not only constitutes the earliest challenges the child faces but also the foundation 
for later emotional life continuing into adulthood. In Klein's view, failure to negotiate satisfactorily the first two phases - the paranoid/schizoid and the depressive position - sows the seeds of adult neurosis and psychosis. The key to emotional life - the mother imago - is inherently ambivalent and furthermore is the subject of horrific sadistic and paranoid phantasies.

A Kleinian approach thus suggests that the unconscious basis of the Durga/Kali image lies in the early experience of every human infant. The radical splitting of the Great Goddess into totally benign, nurturant figures such as Uma/Parvati and demonic figures such as Kali/Rangda closely correlates with the primal experiences described by Klein. This ambivalence, we have seen, is inherent in the very nature of the infant's early experience of the mother. Furthermore, the terrible Devouring Goddess, who turns upon her own creations and devours them, is equally prefigured there. The iconography of the Balinese Durga - the emphasis on fangs, lolling tongue, sharp talons, and the frequently depicted casual gnawing on an infant - emphasises the central theme of oral greed. The ornaments - earrings, necklaces and garlands of dismembered body parts: heads, skulls, chopped off hands and arms, strings of entrails - evoke the phantasy attacks on the mother's body and its contents, and the retaliation expected in kind. The infant does not simply want to kill the mother; it wants to rip her apart with teeth and nails, and suck and scoop out all her body contents. The huge body of the goddess, with its heavy breasts and belly, depicts the mother's body full of milk, excrement, babies and all that the child desires to grab for itself, but now this treasure house of riches becomes a looming monster about to obliterate the child.

We do not need to look to cultural factors to interpret these images; they are the unconscious phantasies described by Klein writ large. Yet they are also clearly cultural forms. The basis for such forms lies dormant in all human beings, we might assume, but the question for the cultural analyst remains: why have such horrific images been worked into culturally elaborated symbols?

\section{The Goddess and the Witch}

I have argued elsewhere that the universality of the image of the witch owes its origin to the phantasies of the Terrible Mother described by Klein. The Balinese Durga's link to witches and witchcraft has already been noted. Yet while many cultures have beliefs in witches, how often do we encounter Devouring Mothers as goddesses? The witch, I have argued (Stephen 1999), is in essence a projection of guilt and anxiety - a projection of the 'bad breast' — and is a figure provoked in times of loss and bereavement. 
A Terrible Devouring Goddess, who is not merely some kind of minor symbolic figure but explicitly an important aspect of the Great Goddess, creatrix of the whole physical universe, is clearly significantly different from a witch figure. She brings into consciousness something most of us, and probably most cultures, would prefer to deny: the deep ambivalence in our most primal experience of love and nurturing. Encountering this terrible aspect of the goddess is to face the very roots of our emotional being. It expresses a fundamental truth about human nature and the very nature of embodied existence. In terms of its spiritual significance, it brings the seeker after truth to recognise the inherently conflicting nature of human love: its origins in fear, anxiety and guilt. This, however, is not a cause to reject human love but to seek that which transcends it and thus to move beyond the dualities of love and hate, good and bad, positive and negative, creative and destructive that limit the operations of the mind, as we find in the philosophical teachings of Tantrism (Avalon 1974; Feuerstein 1998).

At a more mundane psychological level, we can see that whereas the witch is a product of unconscious 'splitting', the goddess is rather an attempt to bring the unconscious identification of the mother as the bad breast/object into awareness. The image of Durga involves recognition of the deep ambivalence that human beings have towards their first love object: the mother. As such, this cultural image surely serves to bring into awareness both sides of the ambivalence, thus resolving it for those who engage deeply with the symbol. By openly stressing and exploring both positive and negative aspects of the unconscious mother imago, these cultural forms enable the undoing of the unconscious splitting of the feminine and thus avoid the need to project the 'bad mother' onto actual women.

Of course, it might also be that the image of the Terrible Mother can be employed in a defensive manner, enabling the worshipper to identify (projective identification) with the Terrible Mother, as in Balinese witchcraft and sorcery (Stephen 2006), so that the victim becomes the persecutor. On the whole, however, at least in Bali, the cultural imagery that vividly depicts both sides of the ambivalence attached to the mother imago helps to foster cultural attitudes towards women that recognise both their gentle, nurturing and loving capacities and the awesome power they hold. Woman indeed is an embodiment of Sakti, the power of the material world, and deeply revered as such. In relation to woman, the male represents spirit rather than matter, but just as Shiva is powerless to bring the physical world into being without Sakti - his creative energy - so the human male is powerless without his consort.

Although I would not want to make such the proof of my arguments, the position of women in Balinese culture - both in the past and today - tends to support my position. Balinese women are respected and valued, and value themselves, as 
females in a way that is quite different from Western cultures, where the women who are respected are those who have succeeded in a man's world. In a book first published in 1937 and still in print, Miguel Covarrubias (1973:44-5) noted the high status of Balinese women, their role as sellers and moneychangers, their dominance of local markets and their economic independence in general:

A woman has definite rights; the income she derives from the sale of her pigs, her weaving, or the garden produce she sells in the market is her own, and she may dispose of her belongings without the knowledge of her husband. Most women are not only economically independent, but contribute to the expenses of the household. A woman's debts are her own and her husband is not liable for them. The women keep the finances of the family and control the markets. (Covarrubias 1973:83)

He also observed in family life 'a strong feeling of equality, of politeness, and friendly frankness in the relationship between husband and wife' (Covarrubias 1973:155). Although Balinese have definite ideas about the type of work appropriate to the different sexes, Covarrubias explains that this by no means meant that women were confined to the home and domestic duties only. Indeed, they routinely undertook such labour as 'transporting building materials, carrying coconuts...delivering charcoal, or obtaining broken coral from the beach to make lime', and even house painting and masonry work (1973:82). These remarks are as apposite today as they were more than 70 years ago. As any visitor to the island can observe for themselves, Balinese women still work as labourers on the roads and building sites, and in the rice fields; they are still active as traders and sellers, and many are taking advantage of new opportunities available in business, tourism and government service. ${ }^{9}$

Well-known Balinese author, public commentator and psychiatrist Luh Ketut Suryani (2003:42-9) observes that Balinese Hindu women are not taught to think of themselves as weak or as of less strength and ability than men, as are females in many other - including Western - cultures. On the contrary, she points out, Balinese Hindu women are deeply respected and honoured as mothers, as the source of creativity and nurturing, indeed as emanations of the great Mother herself, while their propensity for materialism, greed, destructive anger and jealousy is equally recognised. The beautiful, gentle human mother quickly takes on monstrous form if not given her due. In Bali, the power of the Mother is the basis of all life, activity and success - and of all destructive and negative forces as well. In a study of contemporary Balinese artist Ketut Budiana, I have described his most compelling inspiration as 'the power of the Mother':

9 Nineteenth-century travellers and explorers made similar observations concerning the high status of Balinese women. See Geertz (1980:93) and Vickers (1989). 
Budiana's works reveal that the Goddess, in her many refractions, can take forms both beautiful and terrifying. She is the tender loving mother who gives birth to and nurtures all beings; she is the hideous ogress who devours and destroys all in her path. This dual aspect of the Goddess/Mother is central to knowing and understanding the nature of her power. Indeed in Budiana's works, as in Balinese religious art in general, monstrous figures of the divine mother predominate over the gentle and benign. The Mother is not only the origin of life; she is also the origin of death, and womb and tomb are often equated. In the womb, material elements are brought together to form a body that is the vehicle for a new life... Life and death are part of a continuous cycle of transformations of physical substances into different forms. (Stephen 2005:48)

The unconscious imagery is there for all to draw upon, but how that imagery is employed by different cultures links, I believe, to cultural ideas concerning gender identity - and to misogyny and violence towards actual women in real situations.

Women also fear the mother imago; indeed, they have especially strong guilt related to phantasised attacks upon the mother's body. Female psychosexual development, in Klein's view, involves a deep-seated fear that they have been wounded or maimed by the mother, in return for their attacks upon her. I have argued in more detail elsewhere that this unconscious belief leads to a sense of inherent badness or weakness, which results in women feeling themselves to be inferior (Stephen 2003). They thus become vulnerable to, and easily convinced by, cultural images that portray them as inferior beings to men. Where men introject the good aspect of the mother imago and project the destructive and inferior aspects onto women - as we can see vividly depicted in many male initiation cults - women come to accept this projection as it meshes with their own unconscious phantasies of being damaged by the mother.

Carl Jung (1980:37), who believed that the Mother Figure constituted an archetype in the human unconscious, also drew attention to the deep ambivalence attached to this figure and to the many symbolic representations of the Terrible Mother, including Kali. He argued that in patriarchal religions, such as Christianity, the removal of all feminine figures results in an impoverishment, and a failure to engage with the fullness of those symbols of the sacred that arise naturally in the human mind. 


\section{Klein and Vengeful Mothers in Ilahita}

In their important comparative study Gender in Amazonia and Melanesia, Gregor and Tuzin (2001:338) observe that gender distinctions play a key role as organising principles in Hindu Tantrism, as well as in the male initiation cults on which they focus. My argument in this chapter has been that the Tantric figure of Durga in Bali, although it is based on 'splitting', serves as a cultural symbol to undo the split and its defensive consequences. I have argued elsewhere (Stephen 2003) that male initiation cults in the New Guinea Highlands can be understood as classic Kleinian defences against the guilt and terror provoked by the splitting of the mother imago. Gregor and Tuzin's comparative work enables me to apply my arguments more widely to include the cultures they examine, and thus to elaborate on the differences with Balinese Tantrism.

Male cults, as Gregor and Tuzin point out, are prevalent not only in Amazonia and Melanesia but also in Aboriginal Australia, and echoes of them remain even in Western culture in exclusively male clubs and organisations. Their psychoanalytic interpretation clearly identifies the defensive nature of the cults and the insecure masculine identity that they serve to defend. A Kleinian perspective, which Tuzin (1997:122) acknowledges as especially pertinent to his data, can help, I think, to elucidate yet further the nature of the unconscious desires and phantasies involved in the cult rituals. I will focus my discussion on six important features Gregor and Tuzin identify as central to the cults found in 'Melazonia'.

\section{The Matriarchal Myth}

The 'myths of matriarchy' that characterise the cults are summarised by Gregor and Tuzin thus:

The myths tell of a time when the women discovered, invented, or possessed the cult objects, bullroarers, flutes, or trumpets that are the central symbols of the men's cults. These objects permitted the women to dominate the men or at least to live apart from them...Banding together, the men forced or tricked the women into giving up the sacred objects, resulting in their possession of the generative powers of the flutes, the reordering of society, and, in some case[s], the establishment of patriarchy. (2001:310)

The primal unconscious phantasy that the Mother is possessed of all good and desirable things, and the infant's desire to rob her of them, is clearly reflected in this mythic structure, which, like a dream, provides the fulfilment of the wish. The desire to rob the Mother is now realised, but with this satisfaction come 
guilt and fear of the Mother's terrible retaliation. These 'myths of matriarchy' reflect in barely disguised form the central phantasies that constitute what Klein refers to as the 'paranoid/schizoid position' described earlier in this chapter.

\section{The Importance of Body Imagery}

There is much acceptance in anthropology that the body provides a natural symbol for society and many other things as well (Gregor and Tuzin 2001:339), although why certain substances and structures should be privileged over others is not so clear. Few anthropologists, however, consider the unconscious significance of the body. From a Kleinian perspective, the body that provides the template for unconscious phantasy is the Mother's body. The maternal body is believed to contain every good thing the child desires: milk, food, babies, excrement and the father's penis, all of which the Mother is thought to be withholding for her own enjoyment. Klein observes:

I have found that aggressive impulses and phantasies arising in the earliest relation to the mother's breast, such as sucking the breast dry and scooping it out, soon lead to further phantasies of entering the mother and robbing her of the contents of her body. Concurrently, the infant experiences impulses and phantasies of attacking the mother by putting excrements into her. In such phantasies, products of the body and parts of the self are felt to have been split off, projected into the mother, and to be continuing their existence within her. (1993c:142)

Such nightmarish combinations of body parts, male and female genitals, and body substances are just what form the symbolic material elaborated in male cults. Gregor and Tuzin observe: 'The detachability of genitals from their owners anticipates their mutability as male and female organs. Penises, clitorises, vaginas, anuses, breasts, mouths, noses and tongues are symbolic permutations of one another. They condense, merge, and differentiate' (2001:313).

The Mother's body containing the Father's penis is a key Kleinian phantasy, and the core of the figure of the combined parental imago (Klein 1993b:79). The Father's penis is also equated with babies (and faeces) contained in the Mother's body (Klein 1993b:78), providing an exact parallel with the apparently bizarre idea of the Gimi people of Highlands New Guinea that 'fetuses are conceived of as phalluses, with the newborn's fontanel as the urethral aperture' (Gregor and Tuzin 2001:313). 


\section{Reproduction and Procreativity}

Male cults, as Gregor and Tuzin (2001:314) observe, typically focus on concerns with reproduction and creativity in general, asserting that both are the exclusive province of men. This is clearly a defence against male fears of precisely the opposite, and correlates with the primal envy inspired by the Mother's body. According to Klein, the phantasy image of the 'good breast' is the prototype of all creativity:

I would not assume that the breast is to him [the infant] merely a physical object. The whole of his instinctual desires and his unconscious phantasies imbue the breast with qualities going far beyond the actual nourishment it affords.

We find in our analysis of our patients that the breast in its good aspect is the prototype of maternal goodness, inexhaustible patience and generosity, as well as creativeness. It is these phantasies and instinctual needs that so enrich the primal object that it remains the foundation for hope, trust, and belief in goodness. (Klein 1993d:180)

Thus, in unconscious phantasy, the Mother is the source and prototype of not only sexual and reproductive power, but of all cultural creativity as well, and thus the focus of intense envy.

\section{Women and Projective Identification}

In an article entitled 'Male Mothers and Cannibal Women', I have argued at length that male initiation rites in Highlands New Guinea are cultural fantasy systems involving a splitting of the mother imago into exclusively good and bad parts, the former being appropriated symbolically by men, the latter being projected on to actual women (Stephen 2003). Thus, men ritually assert that they give birth to and nurture if not all human beings, then certainly the most important: men. Women on the other hand are seen as dangerous, polluting and weakening to males, and capable of producing only unimportant females - or indeed, if we look to the beliefs of the Gimi people, as inclined to devour all offspring unless subject to the controlling influence of men!

Similar if not identical phantasy processes of splitting, appropriation (projective identification) and projection of the mother imago are evident in the broad spectrum of cultures that Gregor and Tuzin consider. Male cults 'project a view of women as dangerous and powerful', while men take on the procreative powers of mothers for themselves (Gregor and Tuzin 2001:321). 


\section{Secrecy, Vigilance, Terror and Violence}

Having, in unconscious phantasy or myth dream, successfully stolen all the desired things the maternal body is felt to contain, the culprit is then consumed by paranoid fears of the Mother's retaliation. In order to ward off the Mother's revenge, secrecy must be preserved at all costs, but the fears are by no means abated; indeed, the more intense the activities of the cult, the greater are the fears of revenge by the Mother. It is not simply men's insecurity in relation to their masculinity, though there is that of course, but their guilt concerning the theft of the Mother's power, and their intense fear of her revenge, that charges their emotional investment in the cult with such force. Guilt and terror, not merely insecurity, provide compelling motivation. 'Secrecy', 'vigilance', 'terror and violence' (Gregor and Tuzin 2001:316, 318,319) are the hallmarks not only of these male cults but also of the paranoid/schizoid position described by Klein.

\section{Phallic Aggression}

The desire to attack, destroy and control from within the maternal body is central to the Kleinian paranoid-schizoid position:

From the beginning the destructive impulse is turned against the object and is first expressed in phantasied oral-sadistic attacks on the mother's breast, which soon develop into onslaughts on her body by all sadistic means. The persecutory fears arising from the infant's oralsadistic impulses to rob the mother's body of its good contents and from the anal-sadistic impulses to put his excrements into her (including the desire to enter her body in order to control her from within) is of great importance for the development of paranoia and schizophrenia. (Klein 1993a:2)

The cultists' phallic aggression against women - be this rape or murder (Gregor and Tuzin 2001:320) - might thus be understood as an acting out of unconscious phantasies of destroying the Mother.

\section{The Demise of a Cult: Opportunity for reparation?}

From the Kleinian perspective argued here, the 'anguish of gender' identified by Gregor and Tuzin (2001) is generated by men ritually embracing the paranoid-schizoid phase of emotional development, splitting the Mother and appropriating for themselves the characteristics of the 'good breast' while projecting on to actual women the 'bad breast'. No wonder the cults have myths of an original theft from the Mother; this is precisely the nature of the phantasies Klein describes. The fears of the men that women will find out are 
fuelled by the paranoid fears of retaliatory attacks from the Mother. The cults serve to provide a defence against envy and fear of the Mother, but they come at the price of continuous paranoia. By dismantling the cults and admitting their sins, as occurred in the case of the Ilahita Tambaran cult (Gregor and Tuzin 2001:326-8; Tuzin 1997), the men, it seems, might now be able to enter the reparative stage, which begins in mourning and loss but at least provides the opportunity to attempt to repair the damage done in phantasy to the Mother.

The paranoid/schizoid position moves into the depressive position as the child begins to fear that, in his attempts to destroy the bad Mother, he has injured, damaged or even killed the good Mother. A growing sense of loss and depression can be overcome only by the repairing of the dead or dying Mother imago so that she is restored in phantasy as a good inner object. This process of reconstruction Klein terms 'reparation', and in her view it is crucial to normal emotional development. The child unable to make reparation remains locked in the paranoid/schizoid position and this provides the basis for psychosis in adult life.

Tuzin (1997) describes the cultural disintegration and sense of mourning and loss that followed the deliberate unmasking of the Ilahita Tambaran cult. For him, the disintegration of the cult, with all its admitted abuses and even horrors, led to cultural chaos and a worsening of actual relationships between men and women in Ilahita society. He concludes from this experience that the Tambaran cult had served in a positive manner to provide men with 'sanctuary' - a ritual space wherein a painfully acquired sense of masculinity might find shelter. He argues that male gender identity is more difficult to achieve than female, which is based, it would appear, on women's natural physiological attributes and the comparative psychological ease with which girls might identify with mothers (Tuzin 1997:191-2, 228). At this point, however, a Kleinian perspective would challenge his argument.

\section{Masculinity, Femininity, and the Mother}

As Tuzin himself points out, in examining male cults, we are not simply dealing with gender relations as such; rather, we are dealing with the unconscious relationship to the first object, the Mother.

What men did not realize was that while the Tambaran may have engendered fears at one level, it dissipated fears on another. Those fears, older and more primitive than the Tambaran, were not really fears about women at all, but about Mother - though, of course, it was and is women who suffer because of them. (Tuzin 1997:177) 
In turn, this primal relationship determines how gender identities are formed and what is considered to be the proper relationship between genders.

But is masculine identity more difficult to achieve, as Tuzin suggests, than female identity? I have argued elsewhere (Stephen 2003) that women are more prone to see themselves as damaged and inferior, especially if subjected to male ideology along these lines. Freud's notion that women in unconscious phantasy picture themselves as castrated men has, understandably, not been popular with feminists. Yet I think there is a truth in Freud's insight that women feel themselves to be wounded - a truth that is developed and clarified by Klein, who shows that female gender identity is much more complex than usually assumed. The girl has her own pressing fears and guilt concerning her phantasy attacks on the Mother. The unconscious belief that the inside of her own body has been damaged in retaliatory attacks is, according to Klein (1994:225-7), confirmed by the onset of menstruation - a fear that is not overcome until she bears a healthy child of her own, and sometimes not even then. According to Klein, the girl's progress through the oedipal phase is in fact more difficult than the boy's, since the male child eventually returns to his original love object, his mother, while the girl has in the end to reject the mother, her first love object also, and turn to the father and other males:

There are great differences in the Oedipus complex of the girl and boy, which I shall characterize only by saying that whereas the boy in his genital development returns to his original object, the mother, and therefore seeks female objects...the girl to some extent has to turn away from the mother and find the object of her desires in the father and later on in other men. (Klein 1993e:252)

We can see from this perspective that female identity and relationship to the mother are much more problematic than is recognised by some feminist theorists such as Chodorow, as quoted by Tuzin (1997:228). I think any argument that male identity is more problematic than female needs qualifying. Rather, both genders founder on the reef of the Terrible Mother, but in different ways: male envy and fear of retaliation, female envy and the fear girls have that they have already been attacked and wounded. Thus, unconscious female fears that the insides of their bodies have been damaged easily mesh with male insistence on female 'badness' and inferiority. Such fear reinforces the practical circumstances of child-bearing and nurturing that tie women to these tasks. Men are indeed fortunate to be able to convince women that all they are fit for are the menial tasks of caring for children, when really it is men's control of cosmic or cultural forces that constitutes real creativity - be this making money or ritually ensuring fertility and procreation. As technology comes to free women from the slavery 
of child-bearing and nurturing, or at least gives them the choice, the question of who will produce children becomes critical — much as Tuzin's Ilahita Arapesh men feared. Who will willingly choose the drudgery of women's labour?

If men continue to attempt to appropriate the Good Mother for themselves, while trivialising and demeaning women by projecting onto them the Bad Mother, gender relations will continue to be dominated by unconscious fears of, and actual violence towards, women. Evidently, this is a situation that prevails far more widely than the male cults of Melazonia, including contemporary Western societies. Klein's insights suggest that both men and women need to become more aware of the unconscious power of the Mother imago. Where women are culturally encouraged to identify with both negative and positive aspects of the mother figure, as in Bali, I think they will seek to realise their identity as mothers. Nor is it enough to assure women that they are only really fulfilled as mothers; how can they accept that when everything associated with women and children is in actuality trivialised? All they are good for then is second best. Is it possible, as some believe (McDermott 2003), that Western women can successfully identify with the goddess? This clearly will depend on how Western men can respond to such identification.

\section{Defences Against Primal Envy}

Gregor and Tuzin point to male envy of women as a theme of central importance in the ritualisation of male gender identity. Yet why should men envy women? As Tuzin (1997:120) notes for the Ilahita Arapesh, the mythic cassowary maiden, Nambweapa'w, was tricked into an 'artful bondage' in which she relinquished her freedom for 'the captivities of childbirth, motherhood, sexual slavery, food getting drudgery, and all the rest' - in short, the traditional female role. ${ }^{10}$ It is obvious that at a conscious level there is very little in women's roles in these cultures to envy, but as Tuzin (1997:177) notes, Ilahita Arapesh fears (and envy) of women are not really to do with women at all but concern the Mother.

Primal envy of the Mother and all she is believed to possess and be keeping for her own pleasure is, according to Klein, a key factor in early emotional development. She identifies several defences used to deal with that envy: splitting, projection, introjection, denial, and idealisation. All, I believe, can be identified with specific cultural attitudes to women: splitting, projection and introjection in Melanesia and Amazonia, denial in modern Western culture, idealisation perhaps in medieval ideals of courtly love and the cult of the Virgin Mary. In contrast, in Hindu Bali, as we have seen, there is a conscious recognition

10 Strathern's (1990) work on women's labour and domesticity might also be considered here. 
in religious symbolism of the ambivalence held by the mother figure, and a deliberate honouring of the double-sided power held by women in their role as mothers.

Might not the Balinese Durga still be the product of child-rearing practices? Do teasing, frustrating or aggressive mothers give rise to images of Durga/Kali, as argued by Bateson and Mead (1942)? Although the figure of Durga in Bali can be understood as a product of 'splitting' the mother imago into good and bad aspects, the fact that she is honoured and worshipped in terrible guise - with the aim of returning her to her benign aspect - reveals that cultural rituals actually serve to undo the splitting. The equal emphasis on both benign and terrible aspects underlines the point that both are aspects of the same figure: the mother. In this way, I believe, unconscious processes are brought into consciousness and the deep ambivalence to the mother figure is made the subject of conscious reflection and indeed spiritual insight. This contrasts dramatically with Melanesian and other cultures where male cults serve to perpetuate the split, appropriating the good aspect of the mother imago for men and projecting the bad on to women. The Balinese Durga, I suggest, provides both men and women with a means of dealing with their ambivalence towards the Mother imago, the results being that men respect women as the embodiment of the Great Mother, in both her aspects, and women are able to identify with both powerful and nurturing aspects of the Mother. Certainly, men are still able to assert superiority in this scheme of things, since female equates with material substance and physical power, whereas masculine equates with spirit, consciousness and transcendence. Yet the two are utterly interdependent and the necessary basis of all existence. It might of course be that such clearly demarked categories could be used as the basis to enforce even more rigid cultural notions of gender inequality, yet this is not the case in Bali.

In my view, Tantrism reflects the opposite of the Melanesian gender situation; in Melanesia men deal with their envy and fear by attempting to ritually appropriate the good aspects of the mother figure (not just female in general, but as Mother). In Tantrism, envy and fear are overcome by bringing into cultural consciousness the negative and acknowledging and honouring both aspects of the powers held by women. The Tantric hero, the vira, is a hero as he is able to confront his own ambivalence. ${ }^{11}$ But this, of course, does not apply to all men - only to the Tantric adept. The esoteric symbols are there available for those who wish to engage with them but, for the majority, defensive responses to the Mother imago, and her carriers, will probably still prevail.

I would expect that certain kinds of child-rearing practices do in fact tend to elicit or favour cultural emphasis on images of the Terrible Mother but that the

11 My view of the vira contrasts with Kripal's (2003) Freudian interpretation. 
psychic images themselves are an inherent part of the human condition. All cultures must deal with them in some way - even if it is to simply repress and deny them, as we find in modern Western cultures - but they then find outlets other than religion; for instance, in the popularity of violence and monster figures in film and entertainment, but that is another argument.

The question remains why do particular cultures elaborate on particular defensive fantasies? Why do cultures in Melanesia, Amazonia and Aboriginal Australia possess such strikingly similar male cults, while Hindu cultures worship Terrible Mothers? I can do no more than raise the question here and make a few final comments. In small-scale, technologically simple societies, unconscious phantasy themes seem to emerge in more direct, less disguised forms, and to be closer to their unconscious roots. This emerged as a major finding from a survey study of the Oedipus complex cross-culturally (Johnson and Price-Williams 1996:7). This finding also applies to the male cults, where the direct parallels with Kleinian phantasies are no less than astonishing. Although the terrible goddesses of Hinduism also seem very direct representations, and no less confronting, a difference emerges in the way the phantasies are culturally employed.

Along similar lines, Obeyesekere (1990:60-1) has pointed out that in cultures such as the Sambia of Melanesia, symbolic systems seem to remain tied to unconscious themes and conflicts, while in Hinduism (and Buddhism) the symbolic systems follow a different trajectory, moving away from primal concerns to link to more refined concepts and understandings. His insights seem relevant to my arguments here about terrible goddesses providing the symbolic means to transcend the unconscious splitting of the mother figure, whereas the male cults provide a defensive reaction against the splitting. As we see in Tuzin's (1997) account of the demise of the Ilahita Tambaran cult, circumstances can change, however, and the defensive mechanisms of the past might no longer suffice, bringing about internal as well as external revolutions. In these circumstances, new cultural systems will eventually need to be developed that can provide the opportunity for reparation to the damaged Mother. It is perhaps too early yet to know how the Ilahitans might achieve that transition, but Tuzin's unique study has captured precisely for us the moment of change.

\section{Conclusion}

Psychoanalytic perspectives of whatever persuasion inevitably direct our attention to what is common to the human condition. As Donald Tuzin has extensively argued in his own work, comparative perspectives in anthropology are essential unless the discipline is simply to wither into relativist trivia; 
a truly human science must engage with what it means to be human crossculturally. The Kleinian approach I have taken in this chapter can, I believe, add to Freudian insights concerning the nature of unconscious phantasy processes. Freudian concepts of ambivalence, anxiety and repression-used to powerful effect by some cultural analysts - can be sharpened and given more explanatory force in view of Klein's understandings concerning the primal forces shaping emotional life. The phantasies she describes, in all their bizarre detail, are to be found in our ethnographies, and the richer these are, the clearer are the parallels with Klein, as I have found with the Ilahita cult and the Balinese Durga.

Critics of psychoanalysis have often maintained that it is demeaning to claim that the religious beliefs of other cultures reflect the fantasies of children and the insane in Western culture. Such arguments, I believe, involve a false reading of psychoanalytic theory, which suggests not that cultural products such as religious beliefs are no different from infantile fantasy or the delusions of the insane but rather that the unconscious mind provides a common stream of fantasy thought on which different cultures draw and then elaborate, and which also emerges in raw, unworked form in the fantasies of Western individuals. The Balinese Durga is a culturally mediated construct, the subject of complex philosophical reflections, mythological elaborations and rich artistic formulations in dance, drama, sculpture and painting. She is quite specific to Balinese culture and yet she encapsulates and crystallises in a very specific cultural form what are also universal themes of the deep unconscious. The same observations equally apply to Ilahita male cults.

The match between the ethnographic data discussed here and the phantasies identified by Klein seem just too specific and too striking to ignore in my view, yet anthropologists in the main rarely bother themselves with psychoanalytic theory, let alone the Kleinian variety. ${ }^{12}$ Perhaps the confronting 'otherness' of such images, stemming as they do from primal experience not usually available to adult consciousness, prevents us from recognising the recurring patterns cross-culturally. Donald Tuzin was an intrepid explorer of these twin dangerous seas of psychoanalytic theory and the comparative method. We who follow in his wake will sorely miss his brave and fair-minded leadership.

12 Witness the complete overlooking of Klein's work by Kripal $(1998,2003)$ in his groundbreaking psychoanalytic studies of Kali. The recent edited study Encountering Kali: In the Margins, at the Center, in the West (McDermott and Kripal 2003) does not so much as list Klein in its index or bibliography. Fossey (2008:4) explicitly rejects Freudian approaches to Rangda, and does not even refer to Klein. 


\section{Acknowledgments}

I would like to thank two anonymous reviewers of this chapter for pointing out several problems with an earlier draft and the editors of this volume for their support and encouragement.

\section{References}

Avalon, Arthur (Sir John Woodroffe) 1974. The Serpent Power: The Secrets of Tantric and Shaktic Yoga. New York: Dover Publications.

Bateson, Gregory and Margaret Mead 1942. Balinese Character: A Photographic Analysis. New York: The New York Academy of Sciences.

Bernet Kempers, A. J. 1991. Monumental Bali: Introduction to Balinese Archaeology \& Guide to the Monuments. Berkeley, Singapore: Periplus.

Covarrubias, Miguel 1973 [1937]. Island of Bali. London and New York: Kegan Paul International.

Emigh, John 1996. Masked Performance: The Play of Self and Other in Ritual and Theatre. Philadelphia: University of Pennsylvania Press.

Feuerstein, Georg 1998. Tantra: The Path of Ecstasy. Boston: Shambhala.

Fossey, Claire 2008. Rangda, Bali's Queen of Witches. Bangkok: White Lotus Press.

Geertz, Clifford 1980. Negara: The Theatre State in Nineteenth-Century Bali. Princeton, NJ: Princeton University Press.

Gregor, Thomas A. and Donald Tuzin 2001. The Anguish of Gender: Men's Cults and Moral Contradiction in Amazonia and Melanesia. In Thomas A. Gregor and Donald Tuzin (eds) Gender in Amazonia and Melanesia: An Exploration of the Comparative Method, pp. 309-36. Berkeley and Los Angeles: University of California Press.

Hinshelwood, R. D. 1991. A Dictionary of Kleinian Thought. Northvale, NJ: Jason Aronson.

Hooykaas, C. 1974. Cosmogony and Creation in Balinese Tradition. The Hague: Martinus Nijhoff. 
Johnson, Allen and Douglass Price-Williams 1996. Oedipus Ubiquitous: The Family Complex in World Folk Literature. Stanford, Calif.: Stanford University Press.

Jung, C. G. 1980. Four Archetypes: Mother, Rebirth, Spirit, Trickster. London and Henley: Routledge and Kegan Paul.

Kinsley, David R. 1988. Hindu Goddess: Visions of the Divine Feminine in Hindu Religious Tradition. Berkeley: University of California Press.

Klein, Melanie 1993a [1946]. Notes on Some Schizoid Mechanism. In Envy and Gratitude and Other Works 1946-1963, pp. 1-24. London: Virago Press.

Klein, Melanie 1993b [1952]. Some Theoretical Conclusions Regarding the Emotional Life of the Infant. In Envy and Gratitude and Other Works 19461963, pp. 61-93. London: Virago Press.

Klein, Melanie 1993c [1955]. On Identification. In Envy and Gratitude and Other Works 1946-1963, pp. 141-75. London: Virago Press.

Klein, Melanie 1993d [1957]. Envy and Gratitude. In Envy and Gratitude and Other Works 1946-1963, pp. 176-235. London: Virago Press.

Klein, Melanie 1993e [1959]. Our Adult World and its Roots in Infancy. In Envy and Gratitude and Other Works 1946-1963, pp. 247-63. London: Virago Press.

Klein, Melanie 1994. The Psycho-Analysis of Children. London: Virago Press.

Kripal, Jeffery J. 1998. Kali's Child: The Mystical and the Erotic in the Life and Teachings of Ramakrishna. Chicago: University of Chicago Press.

Kripal, Jeffery J. 2003. Why the Tantrika is a Hero: Kali in the Psychoanalytic Tradition. In Rachel Fell McDermott and Jeffery J. Kripal (eds) Encountering Kali: In the Margins, at the Center, in the West, pp. 196-222. Berkeley and Los Angeles: University of California Press.

Kristeva, Julia 2001. Melanie Klein. Ross Guberman (trans.). New York: Columbia University Press.

McDermott, Rachel Fell 2003. Kali's New Frontiers: A Hindu Goddess on the Internet. In Rachel Fell McDermott and Jeffery J. Kripal (eds) Encountering Kali: In the Margins, at the Center, in the West, pp. 273-95. Berkeley and Los Angeles: University of California Press.

McDermott, Rachel Fell and Jeffery J. Kripal (eds) 2003. Encountering Kali: In the Margins, at the Center, in the West. Berkeley and Los Angeles: University of California Press. 
Mookerjee, Ajit 1988. Kali: The Feminine Force. Rochester, Vt: Destiny Books.

Schumacher, Stephen and Gert Woerner (eds) 1999. The Rider Encyclopaedia of Eastern Philosophy and Religion. London and Melbourne: Rider.

Obeyesekere, Gananath 1990. The Work of Culture: Symbolic Transformation in Psychoanalysis and Anthropology. Chicago and London: University of Chicago Press.

Stephen, Michele 1999. Witchcraft, Grief, and the Ambivalence of Emotions. American Ethnologist 26:711-37.

Stephen, Michele 2001. Barong and Rangda in the Context of Balinese Religion. Review of Indonesian and Malaysian Affairs 35:137-93.

Stephen, Michele 2002. Returning to Original Form: A Central Dynamic in Balinese Ritual. Bijdragen tot de Taal-, Land-en Volkenkunde 158:61-94.

Stephen, Michele 2003. Male Mothers and Cannibal Women: A Kleinian Interpretation of Male Initiation in the New Guinea Highlands. The Psychoanalytic Review 90:615-53.

Stephen, Michele 2005. Desire, Divine and Demonic: Balinese Mysticism in the Paintings of I Ketut Budiana and I Gusti Nyoman Mirdiana. Honolulu: University of Hawai'i Press.

Stephen, Michele 2006. Imaginary Violence and the Terrible Mother: The Imagery of Balinese Witchcraft. In Andrew Strathern, Pamela J. Stewart and Neil L. Whitehead (eds) Terror and Violence: Imagination and the Unimaginable, pp. 192-230. London and Ann Arbor, Mich.: Pluto Press.

Strathern, Marilyn 1990. The Gender of the Gift. Berkeley and Los Angeles: University of California Press.

Suryani, Luh Ketut 2003. Perempuan Bali Kini. Surabaya: Paramita.

Tuzin, Donald 1997. The Cassowary's Revenge: The Life and Death of Masculinity in a New Guinea Society. Chicago and London: University of Chicago Press.

Urban, Hugh B. 2003. 'India's Darkest Heart': Kali in the Colonial Imagination. In Rachel Fell McDermott and Jeffery J. Kripal (eds) Encountering Kali: In the Margins, at the Center, in the West, pp. 169-95. Berkeley and Los Angeles: University of California Press.

Vickers, Adrian 1990. Bali: A Paradise Created. Hong Kong: Periplus. 